\title{
CONSTRUCTIVE PLEA BARGAINING: TOWARDS JUDICIAL CONFLICT RESOLUTION
}

\author{
MiCHAL ALBERSTEIN* AND NOURIT ZIMERMAN ${ }^{* *}$
}

\section{INTRODUCTION}

II. ThE VANiShING CRIMINAL TRIAL AND THE NEW Roles OF JUdGES

III. THE CRIMINAL CONFLICT

IV. Evaluating AND Designing Plea Bargains From a Conflict RESOLUTION PERSPECTIVE

\section{INTRODUCTION}

The role of judges in processing criminal legal conflicts has changed dramatically in the past decades. A recent NY Times article ${ }^{1}$ provides current data on the rate of jury trials in the Federal courts, according to which in 2015 jury trials were held only in $2.3 \%$ of the cases. The rate of cases ending through a guilty plea has risen from $81 \%$ of the cases in 1980 to up to $97 \%$ of the cases in recent years. The article tells of a federal judge who only after four years on the bench presided over his first jury trial, and another who presided over only four jury trials during his five years as a Federal judge. Judges, then, preside over a decreasing number of trials, and instead are increasingly engaged in various activities to promote and approve plea bargaining. Such activities are not fully regulated and documented, but they can be studied, improved and refined by using methods and concepts from the field of conflict resolution.

- Professor, Faculty of Law, Bar-Ilan University. Visiting International Professor, Alternative Dispute Resolution, Fordham Law School (2005-6, 2013). Principal Investigator of a European Research Commission (ERC) Consolidator Grant 647943/14 "Judicial Conflict Resolution (JCR): Examining Hybrids of Non-Adversarial Justice" (2016-2021). This paper provides a foundation for the criminal aspects of the research and is partly sponsored by this grant.

** Director, ERC Judicial Conflict Resolution research project, Bar-Ilan University.

${ }^{1}$ Benjamin Weiser, Trial by Jury, a Hallowed American Right, is Vanishing, NY Times, August 7, 2016, http://www.nytimes.com/2016/08/08/nyregion/jury-trials-vanishand-justice-is-served-behind-closed-doors.html. 
This article presents the foundation for a conflict resolution perspective for understanding judges' activities in processing criminal conflicts along the different stages of the criminal process, primarily in their work towards plea bargaining: a practice that today in the United States accounts for the most significant part of judicial work in the criminal domain. The article begins with briefly presenting the phenomenon of the vanishing trial and the major role plea bargaining embodies in the United States criminal justice system today. Given that role, the article next discusses the need to broaden the perspective of the function of judges in promoting and designing plea bargaining and diversion mechanisms. It continues by outlining a conflict resolution perspective of the criminal justice system, while constructing the notion of "the criminal conflict." Later, the article proceeds to describe judicial discretion in approving plea bargains in criminal conflicts as a hybrid phenomenon, in that it borrows from both legal and conflict considerations. That part will discuss the intersection of alternatives to adjudication and the judicial work of influencing plea bargains and diversion mechanisms, expanded through a few examples of varying judicial intervention practices, which exist today within the criminal process in the United States and Israel.

The article ends with examining comparative challenges of implementing this perception in diverse legal systems and fields of law. It discusses the differences between processing criminal and civil conflicts, and also the differences among common and civil law systems, which also vary in their rate of settlement.

The major claim is that there is a new terrain of decision-making, which can be captured when studying judicial influence on plea bargains and settlements. Judges' activities within that new terrain can be perceived as integrating perceptions of reconstructive law with perceptions of reconstructive conflict. This new space of judicial discretion brings together elements of retributive justice and legalistic reasoning with possibilities of inserting elements of restorative justice and problem solving into the legal domain.

This article also posits the challenge of institutionalizing and mainstreaming modes of conflict resolution, including restorative justice and problem solving, which already exist at the margins, ${ }^{2}$ into the mainstream of the criminal justice system. Such a process calls for hybridity and integration, and may require changes in legal education and training for both judges and lawyers. $^{3}$ It is true that one significant element of the plea bargaining

${ }^{2}$ See generally Hadar Dancig-Rosenberg and Tali Gal, Criminal Law Multitasking, 18 LEWIS \& CLARK L. REV 893 (2015).

${ }^{3}$ The research aims at comparatively studying judicial work towards settlement, both in the criminal and the civil settings; to examine its reference to conflict resolution, 


\section{CONSTRUCTIVE PLEA BARGAINING}

phenomenon is that it shifts authority and discretion from judges to prosecutors, as most of the bargaining occurs between the prosecution and the defense, without involvement of the court. In this paper, however, we address the role of judges as they still perform the most significant role of reviewing and approving plea bargains. It could certainly be that developing a coherent understanding of that judicial role, one that is based on the conflict resolution perspective offered here, may also create a new, more appropriate balance between prosecutorial and judicial authority.

\section{The Vanishing Criminal Trial And the New Roles of Judges}

The U.S. criminal justice system has seen increased rates of plea bargaining in the last decades, with the latest data informing that plea bargaining is the dominant form of conviction, with more than $95 \%$ of convicted defendants pleading guilty. ${ }^{4}$ This phenomenon, which is common to the civil cases rate of settlement as well, has been named "the vanishing trial" and has received some comments and debates in legal literature.

Some scholars have discussed the plea bargaining process from a negotiation, contractual perspective, ${ }^{6}$ while others have focused on issues relating to defendants' rights and the power that plea bargaining assigns to the prosecution rather than the courts. ${ }^{7}$ Many have criticized this process and its

restorative justice, and other reconstructive methods; and also to improve and promote conflict resolution perceptions for judges by introducing new training modules and new regulation. See generally Michal Alberstein, Judicial Conflict Resolution (JCR): A New Jurisprudence for an Emerging Judicial Practice, 16 CARDOZO J. CONFLICT RESOL. 879 (2015).

${ }^{4}$ DePt. Of Justice, Office of Justice Programs, Bureau of Justice Statistics, COMPENDIUM OF FEDERAL Justice STATISTICS, 20042 (2006). See generally, Yue Ma, Prosecutorial Discretion and Plea bargaining in the United States, France, Germany and Italy: A Comparative Perspective, 12 INT'L CRIM. JUST. REV. 22 (2002); Susan R. Klein, Donna Lee Elm \& Aleza S. Remis, Waiving the Criminal Justice System: An Empirical and Constitutional Analysis, 52 AM. CRIM. L. REV. 73 (2015).

${ }^{5}$ Marc Galanter, The Vanishing Trial: An Examination of Trials and Related Matters in Federal and State Courts, 1 J. EMPIRICAL LEGAL STUD. 459, 459-476 (2004); John H Langbein, The Disappearance of Civil Trial in the United States, 122 Y ALE L.J. 522, 524 (2012); Marc Galanter \& Mia Cahill, "Most Cases Settle": Judicial Promotion and Regulation of Settlements, 46 STAN. L. REV. 1339, 1339 (1994); Judith Resnik, Mediating Preferences: Litigant Preferences for Process and Judicial Preferences for Settlement, 2002 J. DISP. RESOL. 155, 155 (2002).

${ }^{6}$ See generally, Robert E. Scott \& William J. Stuntz, Plea Bargaining as Contract, 101 YALE L.J. 1909 (1992).

7 CANDACE MCCOY, Politics and Plea Bargaining: Victims' Rights IN CALIFORNIA 66 (1993). "Due process advocates have thoroughly criticized the coercive 
extensive use within the criminal justice system for various reasons, the principal ones being that plea bargaining encourages innocent defendants to plead guilty, ${ }^{8}$ penalizes defendants for exercising their right to trial, ${ }^{9}$ and more generally, lacks in justice - for it prefers institutional concerns and efficiency, favoring the court system and prosecution over the defendants' rights and the rule of law. Another significant concern raised in that regard is that unlike trials, which are held openly, plea negotiations are mostly held behind closed doors, and thus lack transparency. ${ }^{10}$

Despite ongoing critique, ${ }^{11}$ the use of plea bargaining today is increasing and reaching globally, as in civil law countries. ${ }^{12}$ Still, it remains debatable whether its use is only a necessary response to court backlog and efficiency concerns, ${ }^{13}$ or whether it has its own merit. This paper claims that plea

overtones of negotiated sentences, which forcefully 'induce' the defendant to waive constitutional rights."; For a discussion of the power plea bargaining continues to assign prosecutors, See generally Stephanos Bibas, The Feeney Amendment and the Continuing Rise of Prosecutorial Power to Plea Bargain, 94 J. CRIM. L. \& CRIMINOLOGY 295 (20032004). "The losers are the defendants and judges, and the winners and prosecutors." Id. at 295.

${ }^{8}$ See Sydney Schneider, When Innocent Defendants Falsely Confess: Analyzing the Ramifications of Entering Alford Pleas in the Context of the Burgeoning Innocence Movement, 103 J. CRIM. L. \& CRIMINOLOGY 279 (2013) (discussing whether and in which circumstances defense attorneys should encourage their clients to enter into Alford pleas in cases of actual innocence).

${ }^{9}$ See Scott v. United States, 419 F.2d 264, 276-78 (D.C. Cir. 1969) (discussing what appropriate inducements prosecutors can utilize in plea bargaining); Gerard E. Lynch, Screening Versus Plea Bargaining: Exactly What Are We Trading Off?, 55 STAN. L. REV. 1399, 1401 (2003) (arguing that plea discounts larger in percentage terms than the defendant's odds of acquittal impose an unconstitutional "price" on the right to trial).

${ }^{10}$ Albert Alschuler, The Defense Attorney's Role in Plea bargaining, 84 YALE L.J., $1179,1270(1975)$ (lacking transparency in plea negotiation creates lack of understanding of process for inexperienced lawyers).

"See, e.g., STEPHANOS BIBAS, THE MACHINERY OF CRIMINAL JUSTICE 87-88 (2012); Lindsey Webb, The Immortal Accusation, 90 WASH. L. REV. 1853 (2015) (arguing that once a defendant pleads guilty, the system is designed to preserve the plea, and appellate courts rarely overturn convictions based on concerns about the accuracy of the conviction).

${ }^{12}$ Maike Frommann, Regulating Plea Bargaining in Germany: Can the Italian Approach Serve as a Model to Guarantee the Independence of German Judges? 5 HANSE L. REv. 197 (2009). In his discussion of the Italian patteggiamento and the German Urteilsabsprachen (plea agreement processes), Frommann writes, "Italy used to be a legal system that was dominated by civil law traditions, before it underwent a drastic reform to introduce plea bargaining, whereas the German legislature implemented plea bargaining into the predominantly inquisitorial trial." $I d$. at 198.

${ }^{13}$ Stephanos Bibas, Plea Bargaining Outside the Shadow of Trial, 117 HaRv. L. REV. 2463, 2471, 2479 (2004) (observing that both prosecutors and defense lawyers have incentives to plea bargain that are influenced by excessive caseloads); Scott W. Howe, The 
bargaining, as well as other modes of avoiding comprehensive adjudication, could have merit if we view it in the light of conflict resolution theory, and if we redefine the role of judges according to the intersection of the legal dispute with the social conflict that underlies it.

\section{THE CRIMINAL CONFLICT}

The function of law as resolving conflicts in society has been commonly considered a byproduct of its authoritative role of determining and assigning rights. Law claims authority, regulates behavior, and provides normative schemes to promote social good. In most of its institutional manifestations, law operates through a system of formal rules established by the state, encompassing criminal and civil affairs. The reference to sanctions is important for the definition of legal norms, and the intense expansion of regulation and legalization of each branch of our daily lives reflects that the need for coercion through legal intervention is an important aspect of current society. Yet, in various research fields today, there is the growing understanding that the existing institutions of law mostly fail to achieve compliance through command and control regimes and that more complex and nuanced responses to crime, violence and conflicts are required in order to promote society. These responses rely on consent and problem solving and pave the way for the understanding of law's central function as conflict resolution and the role of judges as conflict resolution experts. ${ }^{14}$ This new role of persuasion is, therefore, not only a necessity enforced by caseload and efficiency concerns, but also a reflection of a significant theoretical transformation of the understanding of law's function in society.

While such assertions seem fit to civil law, we claim that with the required adjustments, they should apply to the criminal domain all the same.

In his book, "Violence Explained," John Burton, one of the fathers of the field of conflict resolution, criticized the legal system as being "no longer an effective means of social control." 15 Burton writes about the criminal justice system's failure to help eliminate the conditions that have led to deviance and

Value of Plea Bargaining, 58 OKLA. L. REV. 599, 614-15 (2005) (arguing that abolishing plea bargaining would require enormous resources).

${ }^{14}$ See generally William H. Simon, Solving Problems vs. Claiming Rights: The Pragmatist Challenge to Legal Liberalism, 46 WM. \& MARY L. REV. 127 (2004); Amy J. Cohen \& Michal Alberstein, Progressive Constitutionalism and Alternative Movements in Law, 72 OHIO ST. L.J. 1083 (2011).

15 JOHN W. Burton, ViolenCE EXPlained: The SOURCES OF CONFLiCT, ViolenCE, AND CRIME AND THEIR PREVENTION 94 (1997). 
of its failure in assisting individuals overcome the structural problems they have encountered, such as poverty, addiction, or mental illness. ${ }^{16}$

Burton differentiates between two concepts relevant to our discussion of integrating conflict resolution considerations into mainstream judicial workdisputes and conflicts:

Disputes are confined to interpretations of documents or address arguments about material interests in respect of which there are consensus property norms.

Conflicts involve non-negotiable human needs. Many cases of crimes and violence are included in this category. According to Burton, human needs entail: Safety, Belongingness/Love, Self-esteem, Personal Fulfillment, Identity, Cultural Security, Freedom, Distributive Justice, and Participation. ${ }^{17}$ Burton offers "provention" as a way to constructively deal with criminal conflicts: it is a mode of intervention that aims to alter social conditions which brought the crime, and it tries to address the basic needs that underlie what is framed as a legal dispute. Following and expanding Burton's vision, we claim that from an interpretive perspective each legal dispute has a social conflict dimension that can be processed and dealt with within the framework of legal procedures. The challenge is not only to step outside of law in order to deal with it, as Burton suggested, but to address the complexity of such conflicts from within.

What is a legal conflict in the criminal context? Originally, criminal law developed as a mode of sublimating interpersonal conflict into public dispute concerning breaking the formal law and interrupting the social order. ${ }^{18}$ The transformation of tribal and rural law into a more modern liberal framework has produced friction between the state and the defendant, and has repressed the social and interpersonal conflict which underlies this friction. ${ }^{19}$ How do we come back to the underlying conflict, and is it justified? Is it not dangerous to let the offender deal directly with the victim? Is it reasonable to rehabilitate

${ }^{16}$ See generally id.; Ching-Chi Hsieh \& M.D. Pugh, Poverty, Income-Inequality, and Violent Crime: A Meta-Analysis of Recent Aggregate Data Studies, 18 CRIM. JUST. REV. 182 (1993); Sheilagh Hodgins, Mental Disorder, Intellectual Deficiency, and Crime: Evidence from a Birth Cohort, 49 ARCHIVE GEN. PSYCHIATRY 476 (1992); Benjamin R. Nordstrom \& Charles A. Dackis, Drugs and Crime, 39 J. PSYCHOL. \& L. 663 (2011); National Council on Alcoholism and Drug Dependence, Inc., Alcohol, Drugs and Crime, NCADD.ORG: ABOUT ADDICTION (June 27, 2015), https://ncadd.org/aboutaddiction/alcohol-drugs-and-crime ("Alcohol and drugs are implicated in an estimated $80 \%$ of offenses leading to incarceration in the United States").

${ }^{17}$ BURTON, supra note 15 , at 95 .

${ }^{18}$ See generally GEORGE P. FLETCHER, RETHINKING CRIMINAL LAW (2000).

${ }^{19}$ Id. 
and educate instead of treat individuals as adult agents, to seek harmony instead of justice?

We claim that coming back to the conflict should not be seen as a return to the private, pre-modern encounter, but should rather be understood within a social scene in which much knowledge exists as to the sources of crime and the ways to prevent it. Criminology, sociology and psychology provide us with substantial and valuable knowledge about people's devious behavior, the way to constructively deal with it, and the prospects of changing it. Positive criminology ${ }^{20}$ and restorative justice ${ }^{21}$ may help us in doing so. These approaches provide a robust theory that helps return to the conflict not as a private, unregulated encounter but as a complex, social phenomenon. This social conflict perception, as we will refer to it, has ample consequences for judicial work.

As discussed above, criminal conflicts may include problems of addiction, intimate violence, mental health problems, other disabilities, welfare disparities, cultural gaps, and various other realities. A legal system that addresses these kinds of problems should aspire to constructively transform the conditions underlying the conflict, not only to decide the narrow dispute about which legal norm was violated. Such a system addresses the private conflict as constructed by social factors.

Addressing the legal conflict requires a new sensitivity of the parties, one that transcends the perception of the common adversaries to the formal legal dispute. The basic framework for a criminal legal dispute is a dyad of the state and the defendant. In the new approach, parties may include the victim, the community, and various actors who might have either contributed or were affected by the crime, such as the victim or offender's family members, neighbors, teachers and so forth. When victims are involved, restorative acts may constructively transform the conflict; when welfare conditions are poor, improving them is part of the processing; when cultural gaps are at stake,

${ }^{20}$ See generally HOWARD ZEIR, CHANGING LENSES: A NEW FOCUS FOR CRIME AND Justice (1990); NAtTi Ronel \& Dana Segev, Positive Criminology (2015); Michael Braswell, Et Al., Corrections, Peacemaking, AND Restorative Justice, TRANSFORMING INDIVIDUALS AND INSTITUTIONS (2001). For examples of processes of restorative justice that reflect positive mechanisms suggested by positive criminology see Patricia Gray, The Politics of Risk and Young Offenders' Experiences of Social Exclusion and Restorative Justice, 45 BRIT. J. CRIMINOLOGY 938 (2005); Hennessey Hayes \& Kathleen Daly, Youth Justice Conferencing and Re-Offending, 20 JUST. Q. 725 (2003); Natti Ronel \& Dana Segev, Positive Criminology in Practice, 58 INT. J. OfFENDER THERAPY AND COMP. CRIMINOLOGY 1389 (2014).

${ }^{21}$ See generally Hadar Dancig-Rosenberg \& Tali Gal, Restorative Criminal Justice, 34 CARDOZO L. REV. 2313 (2013); Stephanos Bibas \& Richard A. Bierschbach, Integrating Remorse and Apology into Criminal Procedure, 114 YALE L.J. 85 (2004). 
education and integration may be components of the solution. A legal system that addresses the social criminal conflict will strive to transform the conditions which created it. It will aspire to prevent further conflicts of this kind in general, and will work to prevent recidivism of the present defendant in particular. Such a system will address social needs and not merely legal norms, will be oriented towards the future instead of the past, and will aspire for rehabilitation and restoration through consent instead of retribution through coercion. It will carefully borrow from criminology, sociology and psychology, working with developing interdisciplinary methods.

If we accept the premise that the criminal justice system is supposed to address the social conflict, is it possible to institutionalize such an approach and insert it into the current existing adversarial and retributive system? Suggesting restorative justice as an external process may not contribute to fulfill such a goal. Imposing it as a mandatory, preliminary restorative process in some criminal procedures is a better method for changing the system. A more coherent approach may be to establish problem-solving courts as innovating systems. However, these options remain on the margins, and the notion we would like to promote here is that new perceptions of the criminal justice system may be successfully implemented in mainstream activities within the criminal process, and perhaps especially in judicial work related to plea bargaining, as discussed below.

A judge who addresses criminal conflict from a conflict resolution perspective may work with six organizing narratives of conflict resolution. ${ }^{22}$ These various narratives define different modes by which judges may help to transform and reconstruct criminal conflicts, as follows:

Process emphasis. A central theme that inspired the origin of the field of conflict resolution is the concept that "process matters," and that each conflict requires a focused reflection about how to engage with this process. Stepping back from the conflict scene and reflecting about the conflict and the process are acts of judgment deferral, which may philosophically help judges who deal with plea bargains and criminal cases in general. Judges can ask themselves about the goal of a certain hearing in terms of rehabilitating the offender, empowering the victims, and benefiting the conditions of third parties, such as children. ${ }^{23}$ This emphasis may lead to unique practices.

Constructive future-oriented intervention. In conflict resolution, process emphasis is combined with a positive mode of intervention. Judges who intervene in criminal conflicts ask themselves how to improve the situation

${ }^{22}$ Alberstein, supra note 3.

${ }^{23}$ In 1999 an estimated 721,500 State and Federal prisoners were parents to $1,498,800$ children under age eighteen. BUREAU OF JUSTICE STATISTICS, U.S. DEP'T OF JUST., BJS SPECIAL REPS., NCJ 182335, INCARCERATED PARENTS AND THEIR CHILDREN 1 (2000). 
before them, not only how to decide what occurred in the past and how to punish accordingly.

Underlying hidden layer. According to conflict resolution philosophy, the social conditions underlying legal disputes - those which constitute the criminal conflict - are the true essence of the crime that needs to be addressed. Judges should address addiction problems, welfare issues, domestic violence, mental health conditions, and other elements at the core of criminal conflict. Processing these constructively may benefit society and the parties to conflicts. It may also help prevent future crimes.

Hybridity, complexity and deconstruction. The phenomenon of crime is always complex, and the common criminal process tends to oversimplify crime by constructing it as a polar answer of guilty or not guilty. In conflict resolution, "complexifying" the surface of conflicts is a common mode of transforming them. Separating the interest in rehabilitation from that of prevention - balancing retribution with restoration--is a hybrid activity made possible by holding the philosophy underlying the field. Addressing crime as a complex phenomenon that needs to be tackled by deploying various regulation mechanisms and modes of intervention may provide a more effective way to deal with it. Determining the agenda for dealing with various criminal subjects in a manner that will improve them can also contribute to constructive transformation.

Relationship and emotions. In their work, judges can refer to the reality that people are interconnected in relational networks, and can encourage constructive expression of emotions. ${ }^{24}$ In contrast to the common criminal legal procedure, which assumes that offenders and victims are individuals who carry legal rights, the conflict resolution-oriented judge will address the networks of relationships underlying the case. ${ }^{25}$ They may also address in-

${ }^{24}$ See generally JENNIFER NEDELSKY, LAW'S RELATIONS: A RELATIONAL THEORY OF SELF, AUTONOMY, AND LAW (2011) (presenting a comprehensive perception of the relevance of relational thinking for lawyers and legal work in general).

${ }^{25}$ Bibas writes, in that regard: "[e]ven if the state runs the process, human emotion deserves a seat at the table. Emotion is not some raw, blind passion wholly divorced from and antithetical to reason. It is in part cognitive and evaluative and can be educated. Recent scholarship has impressively defended the importance of giving emotion a role in substantive criminal law alongside reason. Emotions are an important part of what makes us human and how we understand and evaluate our fellow humans' actions. Crime excites fear and anger, empathy and indignation, sorrow and forgiveness. Victims need our solidarity; wrongdoers merit our anger but also empathy for their plight and reasons for breaking the law. This rainbow of emotions is central to appreciating and responding to all the parties' stakes in crime. While the parties have emotional stakes, they must not be judges in their own causes; neutral arbiters must reflect upon and filter the competing emotional claims in order to distill justice. It is time to extend the same emotional logic to 
court relationships, such as between lawyers, or between counsel and client. Judges may encourage apologies if they have the potential to amend relationships, they can contain a victim's horror, and they can give victims a voice in court while protecting them from unnecessary and intrusive crossexamination. Judges may also consider relationships with third parties - such as children or elderly parents-when sentencing offenders, and may perceive the State as striving to promote constructive relationship transformation, not only retribution according to criminal codes.

Bottom up work. Although judges are authoritative figures and have power over the parties, conflict resolution philosophy suggests that involving the parties in the decisionmaking process may help in constructively transforming the conflict. Judges who show empathy for the accused, create behavioral contact with parties, and encourage participation and choice, may help to encourage more compliance and improve the quality of the intervention.

Judges who acknowledge the conflict resolution perspective of criminal disputes, whether implicitly or explicitly, may reflect this in various moments within the legal procedure. This mindset can inspire judicial decisions on detention and bail conditions, and will influence their willingness to consider diversion mechanisms and various rehabilitation possibilities. Judges will use this sensitivity when approving plea bargains, and can apply it when discussing sentencing and punishment with defendants. In rare cases in which conflicts do result in a trial, judges will utilize conflict resolution principles when hearing the evidence. They may also reflect their conflict resolution sensitivity when writing a legal opinion.

\section{Evaluating and Designing Plea Bargains from a Conflict RESOlUTION PERSPECTIVE}

Judicial work concerning plea bargaining is often considered mostly passive and reactionary. ${ }^{26}$ Judges are perceived as peripheral figures within the plea bargaining process, considered in itself a negotiation between the State and the offender. ${ }^{27}$ Judges' significant role lies within their authority to approve (or disapprove) the plea after evaluating it. Although judges rarely disapprove a plea bargain, the possibility of them doing so affects the process

criminal procedures. Laymen care whether criminal justice is emotionally sensitive or tone-deaf, and taking these concerns into account should bolster the law's legitimacy." Bibas \& Bierschbach, supra note 21 , at 87-88.

${ }^{26}$ See generally Milton Heumann, Plea Bargaining: The Experiences of Prosecutors, JUDGES, AND DEFENSE ATTORNEYS 134 (1978).

${ }^{27}$ Id. at 150. 
of bargaining and provides a sense of justice and balance. ${ }^{28}$ Judges are supposed to intervene in the agreement between the State and the offender when the sense of justice and legal coherence is disturbed. ${ }^{29}$ They refer to the "reasonableness" of the plea, ${ }^{30}$ perceive it as the common way to deal with criminal cases, and usually focus on the legal considerations that are relevant to the case.

We claim that within this new open terrain of approving plea bargains, judges may be more active in addressing the criminal conflict, thereby constructively transforming it. If the current reality is a culture of settlement and plea bargains, why not focus on it as a constructive landscape for judicial discretion? While the use of plea bargaining emerged from a practical motivation, ${ }^{31}$ and while common literature criticizes plea bargains as trading justice for efficiency, our claim is that the pragmatic drive for plea bargaining provides an opportunity for a more comprehensive conflict-oriented approach to legal cases. ${ }^{32}$ Conflict resolution considerations should supplement the legal considerations currently guiding judge's gatekeeper role in plea bargains.

Consider a judge who examines a plea bargain reached between the prosecution, and the defendant accused of serious property crimes. If this judge was to adopt a conflict resolution perspective at this stage, she might, for example, turn directly to the defendant and make him actively participate in the discussion concerning the plea bargain, and she could attend to the

${ }^{28} \mathrm{Id}$. at 151 (Statement of defense attorney: "The role of the judge is to keep the system honest, so that prosecutors can't be unrealistic, irrational.").

${ }^{29} \mathrm{Id}$. at 152 ("The judge's significance for the plea bargaining process, then, rests in his potential power to upset negotiated dispositions.").

${ }^{30} \mathrm{Id}$. at 148-49 ("The new judge and the experienced judge have at least one thing in common: neither is preoccupied with developing justifications for plea bargaining.... [T] he newcomer is thrust into the court, and he struggles along just to keep his head above water. He reacts to the negotiated dispositions that come before him and, thus, gradually drifts into an acceptance of the plea bargaining system. As he gains experience in the system, he becomes so accustomed to the centrality of the negotiated disposition that he rarely gives much thought to plea bargaining as a 'problem.' Time and time again experienced judges referred to plea bargaining as 'the common-sense way of disposing of cases' or as 'the practical solution for cases.' It was not uncommon for judges who had assumed office without much criminal experience but with a background in civil law to eventually liken the 'reasonableness' of plea bargaining to the 'reasonable' approach followed in negotiating civil cases. Thus, when I pursued questions about plea bargaining, they often fell back on this civil analogy.").

${ }^{31}$ See generally Stephanos Bibas \& Richard A. Bierschbach, Integrating Remorse and Apology into Criminal Procedure, 114 YALE L.J. 85 (2004).

${ }^{32}$ For a similar view, stated with relation to the proposal to integrate ADR procedures within the criminal justice system, see Jennifer Smith, Scrapping the Plea-Bargain, 7 DIS. RESOL. MAG. 19 (2000-2001). 
underlying aspects of the offenses such as poverty, mental illness, lack of education or profession. When discussing the appropriate punishment this judge will not only consider deterrence or retribution, but will also take into account personal circumstances such as the accused being the main caretaker for three children. If judges take a more active role at the stage of designing the plea (and not only of approving it), they may use restorative justice, integrate welfare services, encourage rehabilitation and choice-making, and may facilitate dialogue, all while performing their mainstream activity. Our claim, which applies to civil and criminal conflicts alike, is that judges may integrate settlement considerations of conflicts with considerations of legalism. The intention here is that although judges cannot facilitate restorative justice as a holistic process or promote a comprehensive scheme for problem solving in a common legal criminal procedure, they can still balance considerations of conflict reconstruction with legal considerations about the application of rules. Their use of legal rules may oscillate between mechanical jurisprudence to balancing social policies and principles, or even promoting social justice. Their perception of conflict resolution may reflect response to needs, amendment of relationship, and even engagement with social identities. This process differs from promoting Burton's "provention" and the constructive transformation of the social conflict he posited as an ideal. It is a hybrid activity that entails holding legal considerations in the shadow of conflict resolution considerations and vice versa. Judges may negotiate with the lawyers of the State and the defense on their agreed terms of plea bargaining ${ }^{33}$ and may propose an alternative solution or a trial; $; 4$ they may

${ }^{33}$ For previous research regarding judicial negotiation and the conceptualization of plea bargaining as a negotiation between parties and their lawyers, see Jenny Roberts, Effective Plea Bargaining Counsel, 122 YALE L.J. 2650 (2013); Rebecca HollanderBlumoff, Just Negotiation, 88 WASH. U. L. REV. 381 (2010); David S. Abrams, Is Pleading Really a Bargain?, 8 J. EMPIRICAL LEGAL STUD. 200 (2011); Rebecca Hollander-Blumoff, Getting to Guilty: Plea Bargaining as Negotiation, 2 HARV. NEGOT. L. REV. 115 (1997); Leonard L. Riskin, Understanding Mediators' Orientations, Strategies and Techniques: A Grid for the Perplexed, 1 HARv. NEGOT. L. REV. 7 (1996); Kimberlee Kovatch \& Lela P. Love, Mapping Mediation: The Risks of Riskin's Grid, 3 HARV. NEGOT. L. REV. 71 (1998).

${ }^{34} \mathrm{JCR}$ examines the negotiation that takes place between the judge and the parties. The designated stage of "pre-trial", the unique role of "settlement judge" or, in the criminal context, the first hearings, are all formal means to empower judges in these negotiations. On the intersection between the formal constraints and incentives and "real courtroom" negotiations, see Marc Galanter, "...A Settlement Judge, Not a Trial Judge": Judicial Mediation in the United States, 12 J. L. \& SOC'Y 1 (1985); RoY LEWICKI ET AL., NEGOTIATION: READINGS, EXERCISES AND CASES (2010); Kate Kovarovic, Pleading for Justice: The Availability of Plea Bargaining as a Method of Alternative Resolution at the International Criminal Court, J. DISP. RESOL. 283 (2011); Owen Fiss, Against Settlement, 93 YALE L.J. 1073 (1984); Carrie Menkel-Meadow, For and Against Settlement: Uses and Abuses of the Mandatory Settlement Conference, 33 


\section{CONSTRUCTIVE PLEA BARGAINING}

offer to arbitrate controversial sections in the agreement by limiting the scope of their decision; ${ }^{35}$ they may try to mediate the difference and help the parties reach a plea bargain; ${ }^{36}$ they may attempt to problem solve; ${ }^{37}$ facilitate dialogue, ${ }^{38}$ bring about transformation; ${ }^{39}$ and sometimes may refer the

UCLA L. REV. 485 (1985); Pable Cortes, A Comparative Review of Offers to Settle - Would an Emerging Settlement Culture Pave the Way for Their Adoption in Continental Europe?, 32 C.V.Q 42 (2012); Michael Moffitt, Three Things To Be Against ("Settlement" Not Included), 78 FORDHAM L. REV. 1203 (2009).

${ }^{35}$ Judges function as arbitrators when they promote agreements between the parties that narrow the conflict scope and bind their judicial decision-making authority. On judges taking on a role in "binding Judicial Dispute Resolution" (JDR), see TANIA SOURDIN \&

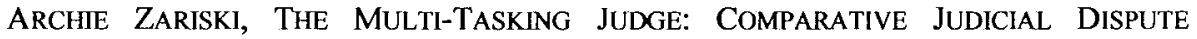
RESOLUTION (2013). For a discussion of judicial arbitration as narrowing down or changing the scope of an agreement, see David B. Wexler \& Michael D. Jones, Employing the 'Last Best Offer' Approach in Criminal Settlement Conferences: The Therapeutic Application of an Arbitration Technique in Judicial Mediation, 6 PHOENIX L. REV. 843 (2013).

${ }^{36} \mathrm{JCR}$ hypothesizes that judges functioning as mediators focus on issues of rights and legal predictions and are directive in their nature, due to their authority and lack of training. See Louise Otis \& Eric H. Reiter, Mediation by Judges: A New Phenomenon in the Transformation of Justice, 6 PEPP. DISP. RESOL. L.J. 351 (2006); Roselle L. Wissler, CourtConnected Settlement Procedures: Mediation and Judicial Settlement Conferences, 26 OHIO ST. J. ON DISP. RESOL. 271 (2011). JCR aims to examine the unique combination of authority and facilitation in judges' conflict resolution activities - by examining mediations that judges conduct in their chambers, in the courtroom, as settlement judges and as decision making ones, and will compare the formal background for such activities and their actual handling.

${ }^{37}$ Behind many legal (and especially criminal) conflicts lie complicating social, economic, and sometimes medical issues. For an offer to regulate such mainstream activity, see Stephanos Bibas, Regulating the Plea-Bargaining Market: From Caveat Emptor to Consumer Protection, 99 CAL. L. Rev. 1117 (2011); Maria J. Glover, The Federal Rules of Civil Settlement, 87 N.Y.U. L. REV. 1713 (2012). Yet, no analysis of the judges' processing and its relation to the underlying conflicts and social problems behind the crime has been made so far. For an example of a special problem solving tribunal developed to address specific problems such as addiction, violence, or mental health disorders, see CENTER FOR COURT INNOVATION, $\mathrm{http}: / / \mathrm{www}$.courtinnovation.org/. With this, no sufficient inquiry has been made into problem solving as a mainstream judicial activity.

${ }^{38}$ Facilitation of dialogue fosters "authentic" relations and encourages deliberation, revelation, reflection, and relational healing between parties who are usually considered locked in identity conflict. For an example of an experimental identity-based dialogue of parties following a class action, see Jay Rothman, Identity and Conflict: Collaboratively Addressing Police-Community Conflict in Cincinnati, 22 OHIO ST. J. ON DISP. RESOL. 105 (2006). We posit that more inquiry needs to be made in order to understand the role of judges in facilitating dialogue among social identities inside the courtroom.

${ }^{39}$ For an elaboration of the therapeutic value of conflict transformation allowed by the process itself, see Robert A. BARUCH BUSH \& JOSEPH P. Folger, THE PROMISE OF MEDIATION: THE TRANSFORMATIVE APPROACH TO CONFLICT (2004). 
defendant to an alternative track such as rehabilitation or restorative justice..$^{40}$ When performing these roles, criminal judges act as conflict resolution experts. ${ }^{41}$

Judges may embody the more active role in reference to plea bargains by investing efforts in helping the parties reach an agreement, being actively involved as sort of mediators in designing the plea, and sometimes generating a concrete formula for settling the case brought before the parties in a preliminary hearing setting. Sometimes such interventions are conducted by a judge who presides on the case and has authority to decide it. In other jurisdictions, such interventions are performed by a sort of "criminal settlement judge," whose sole role is to encourage plea bargaining while having no authority to decide the case later.

In the State of Israel, this process is called "criminal mediation" and its use has become very popular in the past years. ${ }^{42}$ Specific judges facilitate these hearings and the entire procedure remains confidential from the judge

\footnotetext{
${ }^{40}$ See JoHn BRAITHWAITE, RESTORATIVE JUSTICE \& RESPONSIVE REgULATION (2002), for a discussion of Restorative Justice ("RJ") as a collaborative process that grants voices for all affected stakeholders. See HOWARD ZEHR, CHANGING LENSES: A NEW FOCUS FOR CRIME AND JUSTICE (1990), for a discussion of RJ's opposition to retributive justice. See, e.g., Hadar Dancig-Rosenberg \& Tali Gal, Restorative Criminal Justice, 34 Cardozo L. Rev. 2313 (2013) (imagining and articulating more pluralistic notions of criminal procedure). Elements of restorative justice may be incorporated into the criminal justice system, and restorative practices such as encouraging apology, circle conferencing regarding punishment, and creative solutions may be promoted in both criminal and civil conflicts. Another important element in the discussion of judges' roles is the articulation of Judicial Dispute Design; further inquiry needs to be made regarding unique systems that judges implicitly develop in various conflicts and legal encounters, including the hybrids they construct. For existing literature on Dispute Systems Design ("DSD"), see WILLIAM URY, ET AL., GetTing DisPUTES RESOlved: Designing Systems to CUT THE COSTS OF CONFLICT (1993).

${ }^{41}$ For a detailed outline of the ADR work of judges in promoting settlement in general, see Alberstein, supra note 3.

${ }^{42}$ This process is regulated through Article 143a to the Israeli Criminal Procedure Act. For discussion on the merits of this process see the following decisions of the Israeli Supreme Court: CA 6508/05 Ploni v. State of Israel (One of the first Supreme Court cases dealing with the use of criminal mediation in Israeli courts. In this case the court established that criminal mediation could be held based on Article 143a, and emphasized the importance of confidentiality in this process.); CA 723/10 Kastel v. State of Israel (in which the Supreme Court emphasized the centrality of confidentiality to criminal mediation); and CA 8417/13 Ploni v. State of Israel (in which judges were divided as to the question of the legal source for conducting criminal mediation, and in which the court listed a few of the central features of this process; among them, the need for the parties' free choice of mediation, mediation not being subject to rules of procedure, and the need to keep mediation separate from other procedures in the case).
} 
presiding over the case itself. The hearings are held at designated times, at times behind closed doors, and are thus somewhat separated from the day-today hustle and atmosphere of the criminal court. These features create a unique environment that allows for open communication between the parties, and on behalf of the judge as well. A few examples of judges' conduct in such hearings may illustrate the potential of the conflict resolution perspective and its relevance for judges' work when plea bargaining is the core of the procedure.

During criminal mediation hearing observations, ${ }^{43}$ we could identify judges performing different conflict resolution activities such as negotiation, mediation, problem solving, dialogue facilitation and dispute design. The role of the judge in negotiating with both the defendant and the prosecution was dominant, as was the role of the judge as a go-between the parties. Judges evaluated offers suggested by the parties, routinely provided evaluations and estimations for the outcome of the case were it to be adjudicated, and gave their own offers for final outcomes. These evaluations provided a valid framework for the bargaining process and helped define the differences between the parties.

However, the setting offered by criminal mediation hearings allowed judges to do more than simply play an important role in the bargaining process. Judges could involve family members of the defendant, discuss rehabilitation programs and prospects, caucus with attorneys without defendants, and communicate with the defendants themselves (whether directly addressing the defendant or implicitly conveying messages by speaking to the attorneys).

For example, in a case involving a private criminal defamation complaint, the judge constructed a letter of apology with the parties while addressing and discussing the emotional difficulties of both parties. The parties in that case went back and forth, in and out of the courtroom, discussing specific wording of the letter offered by the judge. In another case, which involved the defendant's difficult personal circumstances (addiction, children with disabilities), rehabilitation and treatment possibilities within jail were discussed as part of the creation of a plea. These examples demonstrate both the potential that the focus on plea bargains provides for judges and the various modes of acknowledging the conflict resolution perspective that exist today within criminal judges' activity.

Lastly, the question of judges' work in promoting plea bargaining that also addresses the social conflict should be examined comparatively across different legal systems. In our current research, we are examining the Israeli,

${ }^{43}$ These examples are based on our own preliminary observations in such hearings held in numerous Israeli courts, by various judges, between November 2015 and February 2016. 
Italian and United Kingdom systems: in it, we seek the conflict resolution perspective and look for the possibility of improvement through empirical studies and training. What will be the significance of a continental-law judge processing a criminal conflict? Does the inquisitorial nature of the system imply that judges will be less conflict consideration-oriented, since plea bargains are less expected? Does the judge's tendency to seek truth in a more straightforward mode align with a conflict emphasis? What are the implications of importing a conflict perspective that crosses the divide between criminal and civil law into three legal systems? The idea of the criminal conflict may be less appealing in legal systems in which most cases are adjudicated after a full trial. The question follows: is "the vanishing trial" a globalizing phenomenon which is part of the growth of any legal system? Although such questions are still very broad and imply multiple directions of implementation and development, addressing them in a comparative manner is significant to the perception of law in contemporary society.

The criminal conflict is a broader phenomenon than the legal dispute, and addressing it constructively requires judges to perform unique skills and methods which can be borrowed from the conflict resolution field. Considering the phenomenon of the "vanishing criminal trial," judges in any case are now required to address the reality of conflict and not only questions of legality. This necessity may become a broader terrain for a more comprehensive and constructive processing of legal criminal conflicts. A few examples exist today as to such potential, but a clearer articulation of the jurisprudence of conflict resolution and the various methods which judges may use can help to improve the criminal justice system and provide new perspectives on the role of law in society. 